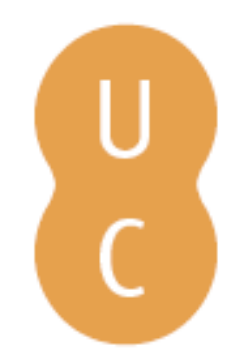

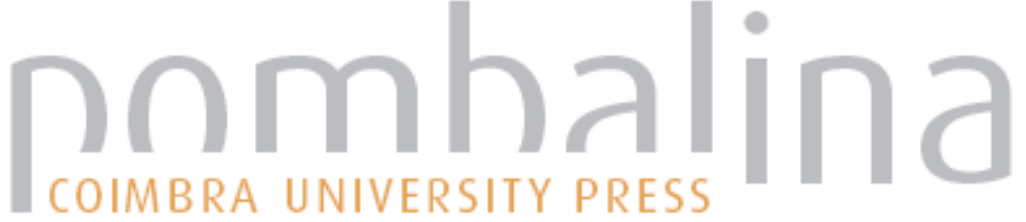

\section{Career Development in Context - Some Historical and Personal Notes}

\author{
Autor(es): Reitzle, Matthias
}

Publicado por: Imprensa da Universidade de Coimbra

URL

persistente: URI:http://hdl.handle.net/10316.2/43650

DOI: $\quad$ DOl:https://doi.org/10.14195/978-989-26-1451-9_3

Accessed : $\quad$ 26-Apr-2023 10:47:31

A navegação consulta e descarregamento dos títulos inseridos nas Bibliotecas Digitais UC Digitalis, UC Pombalina e UC Impactum, pressupõem a aceitação plena e sem reservas dos Termos e Condições de Uso destas Bibliotecas Digitais, disponíveis em https://digitalis.uc.pt/pt-pt/termos.

Conforme exposto nos referidos Termos e Condições de Uso, o descarregamento de títulos de acesso restrito requer uma licença válida de autorização devendo o utilizador aceder ao(s) documento(s) a partir de um endereço de IP da instituição detentora da supramencionada licença.

Ao utilizador é apenas permitido o descarregamento para uso pessoal, pelo que o emprego do(s) título(s) descarregado(s) para outro fim, designadamente comercial, carece de autorização do respetivo autor ou editor da obra.

Na medida em que todas as obras da UC Digitalis se encontram protegidas pelo Código do Direito de Autor e Direitos Conexos e demais legislação aplicável, toda a cópia, parcial ou total, deste documento, nos casos em que é legalmente admitida, deverá conter ou fazer-se acompanhar por este aviso.

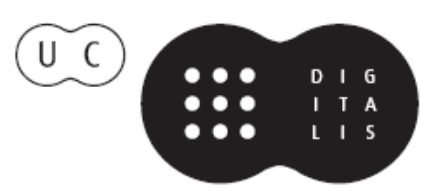


JOAQUIM ARMANDO FERREIRA MATTHIAS REITZLE

EDUARDO SANTOS (EDS.)

\section{CAREER \\ DEVELOPMENT \\ IN CONTEXT}

FESTSCHRIFT FOR

FRED VONDRACEK 


\title{
I I I
}

\section{CAREER DEVELOPMENT IN CONTEXT - SOME HISTORICALAND PERSONAL NOTES}

\author{
Matthias Reitzle, Friedrich Schiller University of Jena, Germany; \\ matthias.reitzle@uni-jena.de \\ https://doi.org/10.14195/978-989-26-1451-9_3
}

\begin{abstract}
In reminiscence and appreciation of two decades of friendship and collaboration with Fred W. Vondracek the present chapter sketches the debate about the impact of contextual constraints vs. personal agency on individuals' career development. It is suggested that scholars' theoretical positions with regard to these two poles are influenced by their socio-historical context as well as their own biographical experiences. In a historical flashback, the major impact of Donald E. Super's work in the 1960s and the 1970s is highlighted. He had coined the prevailing Zeitgeist in vocational psychology when Fred began his career in this academic domain. However, Super's theorizing and work did not remain unchallenged. His strong emphasis on the self and personality was questioned by Walter S. Neff, a very creative spirit who has become almost forgotten in the field. In his 1968 book, one may find precise anticipations of social change phenomena as
\end{abstract}


well as precursors of modern dynamic systems notions applied to career development. The chapter finishes with a critical reflection on new concepts such as protean and boundaryless careers.

Keywords: Career development, personality, agency, context, history, Super, Neff.

\section{Introduction}

I met Fred W. Vondracek for the first time in 1995 during a student excursion of our department to several academic places in the U.S, and it was a most pleasant, welcoming, and hospitable professor that I met. Two years later, Fred visited our department for a couple of months. We were interested in predicting young peoples' timing of consecutive steps in their career development. I had no expertise in the field of vocational psychology and was dependent on his theoretical background. Yet, from the very beginning he treated me as an equal and never tried to indoctrinate me. On the contrary, he insisted on me being the first author of our common product (Reitzle, Vondracek \& Silbereisen, 1998) although he had contributed most of the substance. Over time, we got to know each other better, shared many views on psychology and the academic world in general and became friends. When I learned more about the field and could contribute a bit more substance to our discussions, it became clear that we both perceived career transitions as occurring in context. This insight was inevitable because we were mostly working on data of adolescents and young adults raised in the two different contexts of pre-unification Germany. My impression was that Fred always emphasized a bit more the new oppor- 
tunities and almost unlimited options for agency of eastern young people after unification, whereas I was a bit more skeptical and stressed the market constraints which had replaced the former ideological oppression. Of course, the variety of potential pathways towards self-actualization had increased, but only in principle. There was also an increase in material insecurity and unpredictability of the future. Easterners were not socialized to cope with such a high degree of uncertainty. Consequently, context would have a crucial impact on their job-related as well as private transitions.

\section{Context and Agency}

Since the days in the Berlin Youth Longitudinal Study, I have always been skeptical towards individual agency as the primary driving force in human development, not because I believe in structural determinism, but more so because so many turns and decisions at junctions happen unconsciously, unplanned, or simply by chance. Insofar, I could subscribe to our basic doctrine of "development as action in context" when it was defined the following way: "In short, the action perspective of development is a useful fiction, a paradigm which helps to clarify and systematize basic concepts and methodologies ... we do not wish to imply that action aimed at development is always conscious, deliberate, or rational (Silbereisen \& Eyferth, 1986, p. 5)." Fred often quoted the ideas of Ford and Lerner (1992). They aimed at uniting person and context in their Developmental Systems Theory. This meant finding a theoretically sound compromise between apparently incompatible positions which were illustratively outlined by Ford (1994): 
"Sometimes people are seen as "pilots" of their lives - choosing the destinations toward which they will sail; choosing the means of getting there with some knowledge of the characteristics of their ship and the factors that influence it such as the force of the winds, the currents of life, and the availability of essential supplies ... Another view sees people as machines or "robots" responding automatically to events which impinge on them. In this view, the winds and currents of the sea of life carry a person's ship wherever they may go. The nature of the design of the ship, the power of the currents, winds, and other forces to which it is subjected, determine its directions and movement (p. 10).“

I have never seen humans as will-less objects, neither of social structure nor of destiny. However, the numerous studies comparing easterners and westerners after unification demonstrated to me how powerfully structure can modulate human agency. For example, it has been lamented for decades in Western Germany that women with higher education have increasingly shunned motherhood and that reproduction has mainly been left to lower educational strata. After unification, this trend persisted in Western Germany. In the East, the contrary occurred: Motherhood among well-educated young females increased (Reitzle \& Silbereisen, 1999). With their high qualifications, they maintained employment during the economic restructuring and thus could afford family formation. Due to the wide-spread childcare facilities inherited from the GDR, they were able to maintain their jobs and were not reliant on a male partner. Half of the women from lower educational tracks, instead, had to struggle with unemployment after unification (Reitzle \& Vondracek, 2000) explaining their reluctance to family formation. The basic impression from our data that the post-unification east 
had not turned into a land of plenty just waiting for everybody's agency to grasp the new opportunities, brought me closer to the mostly British literature on structural influences on life course and social exclusion (Bynner, 2001; Bynner \& Parsons, 2002; Bynner, Ferri, \& Shepherd, 1997; Furlong \& Cartmel, 1997; Joshi \& Paci, 1997; Wyn \& White, 2000).

\section{Socio-historical context and biography shape theoretical reasoning}

Whether person or structure prevails in social science theory has a lot to do with the socio-historical context. In the economic growth societies of the postwar 1950s and 1960s, context consisted predominantly of opportunities despite existing social inequality. In Germany, higher education and college degrees were largely the privilege of middle and upper middle class. Working class offspring rarely made it to the highest German school track (Gymnasium) or to a university. Still, there were opportunities to thrive and to even transcend borders between social classes by virtue of ambition, aspiration, and perseverance. In the "golden age" between roughly 1960 and 1974 the macroeconomic markers pointed to seemingly unlimited growth. During this period, German unemployment rates were, with only two exceptions, below one percent. Because of the extreme demand for workforce, foreign workers from Italy, Spain, Portugal, and Turkey were convinced by government agencies to come to Germany. Starting with 500,000 foreign workers in 1962, their numbers surpassed 2.5 million in 1973. In this scenario, career development clearly depended on aspirations, goals, and work-related values. Whether it be in economic self-reliance, preference for leisure and consumption, social 
rise, or personal self-actualization, the labor market offered options and pathways for each goal.

Beside the current socio-historic context of researchers, their past biographies, particularly experiences in their "impressionable years" (Alwin, 1994) during adolescence and young adulthood, inspire their theoretical ideas. Erik Erikson's biography is a case in point (see Noam, 1999). Erikson was initially influenced by the romantic tradition of adolescent "Wanderlust" that represented a youth movement with a strong emphasis on individual freedom and resistance against the prevailing Zeitgeist of technology and industrialization. After the Nazi atrocities forced him to emigrate and uprooted him, questions of "Who am I?" "What is my relationship to religion and to the great ideologies of the centuries?"became salient. These experiences combined with the fact that he was conceived out of wedlock while his mother was married with the Dane Salomonsen. His biological father remained unknown. Upon discovering her pregnancy, his mother fled to Frankfurt, Germany, where he was born as Erik Salomonsen. Then he was adopted by Theodor Homburger, his mother's new husband and took on the name Erik Homburger. After his emigration he renamed himself Erik H. Erikson. His theoretical emphasis on an autonomous intrapersonal identity complies with his long history of unstable social identities. That he repeated his first name to create his own last name completes the story.

Besides Fred's biographical cornerstones on which I will dwell in my conclusion, the prevailing academic Zeitgeist is formative for young researchers when they enter their career. As already mentioned, most often the theories and approaches correspond to the socio-historical context in which they emerge. Following this line of reasoning, I became interested in studying more deeply the arguably most influential scholar in 
vocational psychology of the 1960s and 1970s, Donald E. Super., to learn how the agency vs. context debate was viewed when Fred began his academic career. The fact that Super yields nine entries in the reference list of the recently published book of Vondracek, Ford, and Porfeli (2014), speaks for his unbroken influence in this field.

\section{The advancement of Super's life-span, life-space approach}

In Super's early writings (e.g., 1953) occupational choice was the core topic. Point of departure for Super was the work of Ginzberg, Ginsburg, Axelrad and Herma (1951). The major pillars of their theory were the following propositions: Occupational choice is a process of some ten years, it can be subdivided into the three periods of fantasy choice, tentative choices at around age 11 , and realistic choices starting at around 17. The process of occupational choice was thought to end in a compromise between interests, capacities, values, and opportunities. In addition, the process is irreversible because it needs considerable investments of time, money, and adjustments of the ego. Context had only begun to appear in the form of "opportunities." The emphasis, however, was on the person's developmental sequence. This referred to all persons universally. For Super (1953), this approach was too coarse. He criticized that the concept of interests was underexposed, that individual differences were not acknowledged, that persons had the capacity for a variety of successful careers, that the formative and canalizing force of role models was overlooked, that the existence of career patterns contradicted the irreversibility claim, that the complexity of person-environment interaction was underestimated, and last but not least, that there was no 
account of a desirable match between work and the remaining facets of life such as family, leisure, friends etc. The critique already contained many "modern" elements with regard to humans as complex person-environment systems. Still, the self and context were treated as separate entities which must be reconciled by some process of adaptation.

In a later paper (Super, 1956), context was introduced as a type of moderator imposing different foreclosure-like choices on persons with similar aptitudes: "This kind of interaction between individual and environment might be illustrated by two boys, each with considerable fine finger dexterity, one growing up in a Swiss mountain village, the other in a middle-class city family (p. 250)." The former will become a watchmaker, of course, because his manual skill is cultivated, praised and reinforced in his watch-making family. The other boy, instead, is socialized to a more sophisticated expression of his dexterity in an artistic or scientific domain. He might be driven by his more intellectual context to becoming an engineer. Context canalizes but does not impede. In the worst case, the context may socially disapprove the initial choices and aspirations: "Thus a boy may attempt to meet his need for status by using his artistic aptitude, but, on finding that artistic success is not valued by his peers and brings ridicule instead of praise, may give up his artistic endeavors to try some other status giving activity (p.251)." There is some contextual influence on boys'(!) occupational choice through approval/disapproval from significant others. This, however, has nothing to do with structural constraints.

Some years later (Super, 1969a), the scope was extended to career development across the life-span: "A career is a sequence of occupations, jobs, and positions occupied during the course of a person' working life (p. 3)." Continuities and discontinuities 
in the lives of individuals were taken into account. At this point, contextual constraints imposed by SES and family background were also considered. However, they influenced the starting points of careers only, the careers paths were optimistically upward bound in any case: "His starting point is his father's [!] socioeconomic status, he climbs up the educational ladder at a speed fixed both by his psychological and social characteristics and by the resources provided by his family environment. He enters the world of work which is determined by the rung on the educational ladder which he has reached at the time of leaving education for work. He progresses through an entry job into other jobs, which may or may not be related to each other in constituting a career field in the sense of continuous, progressive achievement (p. 3)." Super conceded that higher levels of education more likely lead to conventional and stable career patterns whereas lower levels yield a higher probability of multiple-trial and unstable patterns. In addition, Super suggested an interdisciplinary view on career development. The sociological focus would be on social allocation (e.g., parental SES), the psychological focus on personality factors (intelligence, interests) and the psychological implications of career steps, and the economic focus on pay and fringe benefits. His core focus remained on psychological factors such as "vocational maturity" which develops in a sequence of "crystallizing a vocational preference, specifying it, implementing, stabilizing in the chosen vocation, consolidating one's status, and advancing in the occupation (Super, 1969a, p. 4)." Change of occupation, in this framework, was deemed a result of mismatch between one's self-concept and one's concept of the current occupation. If important attributes of the occupation are not incorporated into one's self-concept or vice versa, a tendency towards change will occur. This is the case because the superordinate 
goal of this mutual incorporation is self-actualization, and the person is the major force in achieving this goal: "the deciding individual, construing himself and his environment in his own way is a major determinant of his own career, even though he operates in a context of external determinants (p. 7)." Despite this obvious primacy of the person, Super complained in this paper about being perceived as a pure self-concept theorist by some of his peers.

In another paper of the same year (Super, 1969b) he outlined his vision of a vocational development theory in the late eighties. The major focus was again on individuals' self-concept, however, enriched by the idea of the "career tree" that was supposed to visualize the differential career decisions of young people with the same starting point (junior high school), mainly based on the weighting of their verbal vs. spatial-mechanical aptitudes: "Each group, for example the physical science students, is shown in this factor space, and those who changes plans, for example to business organizations, are shown by arrows which start the group from which they are moved and end at a point which shows where they stand on the two aptitudes. In this case, for example, the ex-physical science new-business-organization group is lower on both verbal and spatial factors than is the group which retained the major (Super, 1969b, p. 11)." Besides these talent-related traits, he wanted to get a handle on the differential effects of various types of exploration, intentional vs. fortuitous, systematic vs. random, and self- vs. other-initiated. In closing his vision, Super providently made the success of self-concept, as an overarching theory of vocational development, dependent on macro-contextual conditions: "Surely the importance of the individual as a decision-maker depends on his freedom to make decisions. Self-actualization depends on social mobility, upon the fluidity of the social class 
system, upon the accessibility of educational and occupational resources to the individual (p. 13)."

Ultimately, Super (1980) elaborated the idea of career development as a sequence of choices. At each step, opportunities for choice are determined by previous steps. For example, the amount and type of schooling determines what type of occupations a person may enter. The initial type of occupation and persons' job performance determine later occupational positions open to the individual. The last full-time job is a major determinant of life-style in retirement with regard to retirement income, activities and social relationships. Prior success was seen as sufficient condition for later success. A profound education should almost always lead to a high level initial position. This position combined with excellent performance on the job should almost always lead to a promotion or to a profitable job change etc. As in earlier versions, the starting or decision points were supposed to be socially stratified according to SES and education: "They depend upon the educational achievement of the individual, for in the case of manual workers without special training the decisions are largely those of what kind of manual job to seek among a situationally restricted list and where to seek it, while for executives the decision points depend largely upon how well they have done their latest assignments and what kind of vacancies open up (or fail to open up) as a result (Super, 1980, p. 292)."

Recent decades have shown that even for highly educated persons, achievements at one point may represent necessary but no longer sufficient conditions for an upward career. Particularly, rocky transitions from education to work often become an everlasting burden on each subsequent step ("scarring effect"; Blossfeld, 1989; OECD, 1998), even for well-educated young people. The burst of the DotCom bubble in 2000 had 
young top executives dropped from a luxurious work life to unemployment. A similar fate hit bankers and investment bankers in the financial crises of $2007 / 2008$. Even without these economic shocks, the quest for a job seems to be more detached from self-concept issues today. Vocational decisions no longer aim primarily at self-actualization. Instead "Bread before Bach" as Maslow once stated (Burns, 2010) seems to be the motto for many.

\section{Too much "self" in vocational psychology - Neff vs. Super}

As early as 1970, a controversy between advocates of person and context became visible in Super's review of Neff's book (1968) "Work and human behavior." In a five-page article, Super (1970) extensively defended contemporary vocational psychology, particularly his own contribution, against putatively false allegations of being too person-laden ending with the recommendation that "The book should be read by practitioners and students for its contributions to the philosophy and methods of rehabilitation, but not as a treatise or text on work and behavior (p. 167)." Neff (1970) replied politely pointing to the difference between himself and the mainstream: "In chapter 7, I examine the chief theories of vocational behavior (Super, Ginzberg, Roe, plus mention of the work of such people as Holland and Flanagan), after making it explicit that I believe that this literature is less useful for helping us understand how people become workers than it is for providing insights into how people make occupational choices' (p. 530)."

What was the essence of chapter seven that had so upset? From today's perspective, the conceptual ideas on which Neff based his critique appear sometimes very modern, holistic, 
interdisciplinary, in short, farsighted. Basically, he criticized his coevals with gradual differences for focusing too much on occupations instead of on work and its different aspects and functions in human development. Furthermore, he complained about mainstream's circling around the trinity of abilities, aptitudes, and interests as relatively static personality factors, about the neglect of contextual conditions, thereby attributing choices at each step of career development to "voluntarism and rationalism", about the neglect of emotions, spontaneous heuristics, and chance operating on individuals' career pathways, and ultimately about the disregard of social change steadily altering the contextual conditions for choices. Super was particularly faulted for placing career choice too much in the service of self-concept only, a blurry and ill-defined construct in Neff's eyes:

“To support Super's theory, two general conditions would have to prevail in the real world. First, young people would have to enjoy almost unrestricted freedom in making occupational choices and in shifting from one sort of training to another as circumstances dictate. Second, these young people would have to operate at least as rationally as an electronic computer, in the sense that they would have to be more or less continually involved in matching whatever data they have about themselves to whatever data they have about occupations. Should either or both of these conditions fail to hold, then there is little reason to expect that there will be any generally detectable relationship between the pictures people have of themselves and the occupations they ultimately enter (Neff, 1968, p. 104f.).”

He did not deny that this scenario may apply to some individuals, but he insisted that real life is too complex to boil 
major developmental outcomes down to a few personality variables even if they are allowed to interact with some features of the immediate context such as family, peers, and school:

“... a host of factors must be considered as having some influence on occupational behavior quite apart from the self-concept. Constraints arising from socioeconomic status, the particular aspirations, biases, and predilections prevailing in individual families, barriers posed by ethnic and demographic factors, differences in the relative ease of entry into the different occupations, prevailing stereotypes concerning differential occupational prestige, the various frictions and rigidities which characterize the system of formal education, the influence of prestigious peers and adults, sheer inertia - these are only some of the variables which, more often in combination than singly, may serve to determine choice of occupation ... Occupational activity is too molar as a sphere of behavior to be easily linked to a single kind of determinant ... In one sense, then, Super is too much of a psychologist and not enough of a general social scientist (p. 105)."

Over and beyond his critical appraisals, Neff offered some other modern ideas, e.g., by overcoming the traditional antecedent-consequence thinking of the 1960s. The first one dealt with the idea of transaction within an inseparable person-context unit (cf. the "relational developmental metanarrative"; Overton, 1998): "We should emphasize that we are considering here only one side of what is always a two-sided transaction: between the individual and his surround. Living organisms not only live 'in' an environment; they are in a continuous state of interaction with environmental forces. Human behavior is not only a function of the kind of individual the person happens 
to be, but is also a function of what is happening to him. In the ordinary stream of events, these two sets of conditions of behavior are intertwined (p. 119)." Another notion resembles the idea of circular causation between everyday micro-processes and (changing) higher-order structure in the dynamic systems theory (DST, e.g., Nowak, Vallacher \& Zochowski, 2005; van Geert \& Steenbeek, 2005; Witherington, 2011). In this vein, Neff acknowledged that self-concept and occupational choices are not separable entities. The factors and constraints he had enumerated and a person's way of handling these factors affect not only their choices, but also their self-concept at the same time. Neff's reasoning that at each step of career development choices imply constraints which reduce the person's options is compatible with the DST concept of emergent attractor states (van Geert \& Steenbeek, 2005). The narrowing of the scope of choice is due not only to an increasingly rigid environment, but also to the inertia of an individual's psyche:

"The chief determinants of the increasing restriction of freedom are the frictions and rigidities inherent in the institutional environment. Earlier decisions to take or drop a given school subject can exert a powerful influence on later educational options. Not only does the educational system itself display increasing rigidity with time, but it is psychologically easier to continue on a given course of action than to abandon it and start all over in something else. The result is a series on increasingly restricted compromises between what one wants to do and what is actually available ... Thus, an individual may wind up in an occupation which is relatively incongruent with his actual personal attributes, largely because early and irrevocable choices were made - whether accidentally, impulsively, or simply mistakenly (Neff, 1968, p. 109)." 


\section{Neff's account of social change came true}

Last, but not least, Neff (1968) made an argument for treating context as dynamically as the individuals acting and deciding in these contexts: "In the real world, however, conditions are never constant, and the real world is the locus of Super's research enterprise. Too many things are operative to permit any set of purely personal attributes, no matter, how construed, to bear any very close relation to the kinds of work people are actually found to perform (p. 106).”

As a matter of fact, social change with all its consequences for career development is largely unpredictable. Besides the economic shocks mentioned above, even smooth changes alter the conditions for career development. The German "educational expansion" beginning in the 1960s granted higher education to a broader spectrum of youth. This did, however, not necessarily improve their options for career choice. Until today, there has been an oversupply of youngsters with college degrees in the liberal arts sector while there is a shortage of skilled workers in manufacturing and the trades. The halfhearted introduction of the bachelor/master system in Germany has created bachelors with skill profiles for which many employers felt no need: Too highly skilled for low wages, not skilled enough for good positions. While the political emphasis in Germany has been on higher education for the last decades, the quality of the lower tiers of our stratified school system has suffered. Around 70 percent of the 20 to 34 year-olds without a school degree and more than 30 percent with a degree from the lowest school track ("Hauptschule") remain without occupational training (Anbuhl, 2012). These figures have remained constant since the mid 1990s. These youths in particular suffer from globalization with the increasing export of entire low-skill branches with their corresponding jobs to threshold 
countries. The dramatically changed world of work leaves a considerable number of young people facing the question of whether instead of what with regard to work, particularly in the economically dire contexts of southern Europe. In contrast to the "golden age" outlined at the beginning, a bigger portion of the young generation is struggling at lower levels of Maslow's (1970) need hierarchy today than in the era of unquestioned economic growth and full employment. Paradoxically, this contrasts with a marked enhancement of education, technological progress and a theoretically much greater variety of options and career paths. The price for the greater variety of options seems to be the greater variety of unpredictable risks (Beck, 1992). In sum, the picture has changed from a static match between self-concept and occupation to a dynamic navigation through changing tides and unforeseen rough seas.

\section{How the controversy ended - a balance sheet}

Sometimes vision gets lost. In Thomson Reuters $@$ Web of Science, Neff scores with 21 records, among them a commentary in Science, yields 50 citations and an h-index of 4 . In contrast, Super has 94 entries, 1425 citations and an h-index of 16, aside from numerous academic honors and awards (Savickas, 1995). In recent years, Super has experienced an impressive citation revival after a dip in the curve. His tremendous productivity and the continuous extension of his approach to the role of work and careers in individuals' development across the life-span have granted him an outstanding place in vocational psychology of the $20^{\text {th }}$ century.

Despite his conceptual ideas which appear ahead of the times, Neff's work, particularly his 1968 book "Work and human 
behavior", never gained considerable influence in the field. Super's sending him back to his niche of "the philosophy and methods of rehabilitation" (Super, 1970, p. 167) apparently had its effect. Excellent appraisal by other colleagues did not help to spread the conceptual ideas which ordered the practical advice given in this book: "Work behavior is treated in what the writer calls a 'Transactional Approach.' This means that work behavior is a complex inter-relationship between the person and his work culture.... The book is rich in bringing forth important historical, sociological, psychoanalytical, and psychological aspects of work ... As a final testimony to the excellence of this book, I will be ordering it for my class as soon as I complete this sentence (Perrone, 1970, p. 259f.)." Unfortunately, as professor of psychiatry and psychology in the emerging and controversial field of psychiatric rehabilitation at NYU and SUNY/Stony Brook, Neff was more of an outside observer of vocational psychology than a "member of the gang." Neither personnel selection nor career planning and vocational counseling, the main pillars of this field in these days, were his genuine topics. Last, but not least, there is another marked difference between him and Super. While the latter was an aviation psychologist with the rank of major in World War II (Savickas, 1995), Neff was head of the New York Council of the American Peace Mobilization, a communist-associated organization founded in 1940. Together with ten other teachers, he was suspended from City College of New York in April 1941 as a result of the Rapp-Coudert Committee (Joint Legislative Committee to Investigate the Educational System of the State of New York) hearings. In the same year he wrote a book with the title "Foreign Policy and Peace" (Neff, 1941) published by the New York Council of the American Peace Mobilization that does not appear in his Web of Science records. 


\section{The immortality of good ideas - the dynamic system perspective}

The idea of complex interactions of person and context in the pursuit of mastering one's vocational development over one's entire life course, in short, a transactional model, has survived and is well-documented in the work of Fred Vondracek. After having issued a first cornerstone with the book "Career development: A life-span developmental approach" (Vondracek, Lerner \& Schulenberg, 1986), he has recently put together the distillate of his academic work in the book "A living systems theory of vocational behavior and development" (Vondracek et al., 2014). It touches on all modern ways of thinking about development: a plea for a holistic instead of an atomic or segmental approach, an emphasis on dynamic processes instead of static variable connections, the idea of self-construction and self-regulation instead of being affected by internal and/ or external forces, the idea of feedback loops and action control, and the person and his/her idiosyncratic patterning of biological, psychological, and social characteristics instead of sample-based variable networks as the primary unit of analysis. The focus on the individual may be the fruitful heritage of the experienced clinician and counselor Vondracek.

The notion of systemic functioning is based to a great part on the work of Ford whose book "Humans as self-constructing living systems" was first released in 1987. Since the 1990s, a dynamic systems perspective has increasingly infiltrated developmental science from different angles (e.g., Thelen \& Smith, 1994; van Geert \& Steenbeek, 2005, Witherington, 2007). Despite some conceptual differences, the core element is the structure organizing everyday micro-processes as, for example, individuals' interpreting, thinking, and action, alone 
and in social interactions. Stability of systems is obtained via attractor states which, according to their number and energy levels, evoke flexible (high number, low energy) or rigid (low number, high energy) attributions and responses in everyday processes. Ultimately, the individual attractor landscape can be regarded as personality (Nowak et al., 2005). Its development through everyday interactions is usually a process of selection and focusing, in other words a reduction of theoretically countless options which exist in the beginning: "Conceptualizing personality in terms of attractor dynamics thus captures both the human proclivity for continual change and the tendency to forge and maintain personal stability in one's interaction with the environment. A person's thoughts, emotions, and behaviors may initially be generated in response to situational demands, but over time they come increasingly under the control of stable internal states (cf. Lewis, 2000). With the development of attractors, moreover, there is a restriction in intra-individual variation and the emergence of inter-individual differences ( $p$. 354)." Attractor landscapes are rather inert, change slowly, but may also be spontaneously restructured if the system experiences serious perturbations in the course of major developmental transitions or life events.

Ideas about constraints of repertoires can also be found in Ford (1994). Talking about self-organization, he acknowledged organismic and environmental boundary conditions. With regard to the former, "the best social strategy, humanistically speaking, is to assume that there are few organismic limits on learning potentials and to seek to design environments and methods to cultivate the desired functions (p. 155)." Environmental boundaries, on the other hand, may cause individual differences in performance capabilities (e.g., scholastic aptitude tests) mistakenly attributed to a genetic origin. How the individual 
can deal with an unfortunate high potential in adverse context combination, was insinuated by Ford (1994) in terms of adaptation: "Children born in a city ghetto or in rural isolation will learn to adapt their inborn potentials to their particular environments (p. 157)." This notion could be reformulated as an emergence of context-specific attractors. In the extreme case the alienated inner city young man may form an ostensibly successful street survivor habit, knowing when to hit first, smelling the police in advance, and acting aggressively in case of doubt. The rural local yokel may form a successful law and order habit, knowing how gain influence in a small community, exploiting conformity, portraying himself as the straight patriot. However, both could have become open-minded successful college graduates if raised under more conducive conditions. Thus, in line with the idea of multifinality, similar natural assets may lead to completely different developmental outcomes depending on context. In contrast to Ford's "habit formation" leading to automatized performance capabilities which can be applied efficiently and effectively without requiring primary attention, attractors do not have necessarily positive valence. They may neither be accompanied by immediately gratifying emotions, refer to intentions and desired states, nor yield positive developmental outcomes in the long run (Nowak et al., 2005). Granic and Patterson (2006) present an illustrative example for the emergence of deviant behavior by the build-up, widening, and deepening of a "deviant talk" attractor within a peer group with only restricted normative success.

Coming back to the initial framing of this chapter, namely individual agency vs. contextual constraints, one should keep in mind that attractors are built in everyday interactions with persons from one's prevailing contexts. This line of reasoning suggests that social constraints or even social exclusion with 
regard to career development extend beyond factual obstacles such as material hardship, low quality schooling or the lack of promoting networks. Social constraints also include psychological factors operating in one's context such as, for example, educational aspirations of the family, the prevailing valence of education and work in the neighborhood, successful role models, explorative tendencies fostered by secure attachment, encouragement to try out, early opportunities for mastery, and the current normative climate with regard to career opportunities and the future in one's cohort and social stratum. These factors and climates operate through the filtered and weighted experience of one's everyday interactions with protagonists in one's various contexts thereby contributing to the formation and changing of structure in a developmental time metric whereas structure itself forms, filters and weights immediate experience in real-time ("circular causality", see e.g., Witherington, 2007). One formidable example of a very effective attractor that is unconsciously formed as a byproduct of social class and pedigree is Bourdieu's "habitus" (Bourdieu, 1982). Habitus evolves from concrete interactions with family and upper class peers from infancy onward forming a strong attractor of being a winner, of being in control, of being superior. This attractor is accompanied by appropriate manners, social skills, and a kind of invincible aura. Habitus is introduced into almost every social interaction in such a convincing fashion that interaction results in success and reinforcement. Insofar, habitus not only reflects the material advantage of the upper class context but is an immaterial embodiment of class-typical interaction at the same time.

By accepting the DS way of thinking that personality is not genetically determined but a structure, a landscape of attractors massively influenced by cognitive-emotional micro-processes within the person which are closely linked to interactions with 
other persons, the prominent role of context is undeniable. Except for a few biologically determined assets or constraints representing "pre-wired attractors" (Nowak et al., 2005), the many "selves" in self-direction, self-organization, self-achievement, and self-regulation (Vondracek et al., 2014) are to a considerable degree embodiments of interactions with others. Under a DS perspective, the dichotomous split into person and context, into nature and nurture, and the subsequent attempt to quantify their contributions to developmental pathways, is fruitless because person and context are inseparable entities. Contexts derive their psychological meaning through individuals' transactions only, whereas a completely context-free individual personality does not exist. This view complies with Overton's (2007) relational organicism-contextualism - with a special emphasis on "relational". Under this premise the uniqueness of the individual self is not the uniqueness of persons but the uniqueness of person-context systems. Even unpredictable and idiosyncratic system phenomena such as emergence are not person-borne ("person" used here in the traditional meaning as antagonist of context) but system-borne: "Emergence in a system, the coming into being of new patterns or forms as a result of interactions among the very components that comprise the system - such is the nature of self-organization, both as a phenomenon and as the metatheoretical underpinning of DSP (Witherington, 2007, p. 135)."

What do these metatheoretical considerations mean for career development? The "self" is not a superior being who masters contextual demands and opportunities in a conscious, cognition-ruled, planful and goal-oriented manner guided by feedback loops and subsequent adjustment of action and/or goals. This picture resembles more a heater control than a double pendulum or a Lorenz wheel. In contrast, the movements of living systems through space and time are often driven by 
unconscious forces, are driven by emotions and former emotional experiences, rarely follow a well-elaborated master plan, do not even necessarily move in the direction of a desired state, and perform sudden and unpredictable turns that occur in periods of shaky system states. Whether there is a goal at all and whether this goal represents an energy-rich attractor, i.e. a wide and deep funnel, itself results from system activity, i.e., from person-context interactions.

Considering the role of context in dynamic systems, it can be concluded that system stability has a lot to do with context stability, for better or worse. Granic and Patterson (2006), for example, demonstrated that coercive interaction and deviance stabilize by persistent and script-evoking interaction contexts. In the positive sense, straightforward goal building and goal pursuit performed by stable systems occurs more likely in stable and predictable contexts. As already stated, contexts are multifold at different layers (Bronfenbrenner, 1979) and consist of persons in the immediate environment, a normative climate and culture, material conditions in terms of persons' financial situation, institutions, legislation etc. Even if they are not particularly conducive, a clear definition and long-term predictability of these context facets help a system's stable functioning. Nowak et al. (2005) related the stability of system functioning to the amount of "noise", i.e., the combined effect of a host of biological, cognitive, environmental, and social factors at a given moment. In low noise situations, systems will hover around their attractors irrespective of their strengths. Noise of medium size will destabilize weak attractors. The functioning of the system comes under control of strong attractors only. High levels of noise even erode strong attractors and increase the attention to situational cues: "Under such conditions, in other words, personality represents a fairly weak force in generating behavior (p. 377)." With 
regard to career development, the Great Depression represented a high noise situation. People with various shades of education, work ethic, and career plans were uniformly either running for any job or desperately trying to maintain their jobs for material survival. In other words, their behavior did not mirror too many personality differences, i.e., differences in system functioning. Paradoxically, low noise situations do not produce vast individual differences in behavior either. The overall conducive context allows individuals to tune their behavior according to prevailing norms and generally desirable states. This situation resembles the era of postwar economic growth. The prevailing norms were life-long employment with the same employer, upward mobility, increasing affluence, job satisfaction, clear division of roles in work and household (see the omnipresent "he" in Super's writings), and self-fulfilment through work (for most women through maternity, household chores, and attractive appearance). Sources of variation were differential interests in various job domains, the extent of upward aspirations, and the fit between interest, aptitude and work characteristics.

It comes as no surprise that theorizing about career development then circled around these "self-concepts" and extended to context mainly with regard to the match between the person and the immediate work environment. The private context provided guidance for the formation of interests according to abilities as in the example of the Swiss watchmaker (see above). However, this example has a touch of rigid foreclosure rather than of dynamic systems. Macro-contexts, the economic and demographic situation, the labor market, social class and social exclusion played, if at all, a secondary role in the psychological study of career development. The assumption of context-independent stages and mechanisms implicitly granted these approaches the status of universally valid theories. 
The current situation is probably one of medium noise levels. In industrialized countries, nobody must fear starvation or an end in the gutter. However, upward mobility combined with occupational self-actualization has no longer the normative top rank on most young people's vocational agenda. Maintaining parents' standard of living or even preventing a severe descent from their economic levels has become a major concern (Côté \& Bynner, 2008). Unlike weak noise situations, the current scenario offers an ostensibly greater variety of options, but at the expense of higher risks and a loss of context predictability. Under these conditions, inert biologically "pre-wired" attractors and reactivity to immediate situational demands seem to reign system functioning. Today is neither the time of a unitary rush for survival as happens in massive crises, wars, and dearth, nor the time of a common striving for personal desirable ideals at the top rank of Maslow's need hierarchy in a socially protected and predictable environment. A return to more basic concerns is indicated by the steady decline of social capital in the U.S. (Putnam, 1999). In a similar vein, a marked decrease of participation in voluntary and community associations from 60 to 20 percent has been observed across the birth cohorts of 1946, 1958, and 1970 in the UK (Bynner, 2005). The last three decades have been marked with the label "individualization", often with the connotation of voluntary idiosyncrasy (e.g., Arnett, 2000, 2004). However, the fact behind individualization is that even persons with similar pre-wirings and resources may follow different pathways at crucial bifurcations by virtue of only minor differences in system functioning which, of course, implies influences from the distal context (e.g., social class, ethnicity, labor market, locality), transmitted by interactions with the proximal context (see also Bynner, 2005). In DS terms, our time seems to be the era of multifinality whereas the dec- 
ades of seemingly infinite growth in the 1950 s and 1960 may have been the high tide of equifinality: the majority of the respective cohorts could pursue a successful career whether by talent, parentage, education, diligence, perseverance, or any combination of these factors.

\section{Boundaryless and protean careers - the new stairway to self-actualization for everybody?}

Multifinality is mirrored in the contemporary vocational literature. To find the best fitting occupation is no longer the goal, but the successive build-up of occupational portfolios (Gershuny \& Pahl, 1996). In order to maintain options, young people must accumulate education and preserve their human capital by life-long learning. Despite better schooling and, on average, better formal education, transitions from education to work have become diversified, rockier and have left varying portions of younger cohorts behind ("Getting nowhere", Bynner et al., 1997; "The bottom half", Lewis, Stone III, Shipley \& Mazdar, 1998; "Status zero", Williamson, 1997). In countries such as Spain and Greece, more than fifty percent of young people below age 25 were unemployed in the years 2012 and 2013 (Source: Eurostat). Once the step to employment is accomplished, based not necessarily on one's occupation or training, career development has many faces. This is reflected by novel concepts such as "boundaryless careers" and "protean careers". In short, boundaryless careers are characterized by mobility between different employers (Arthur, 1994), whereas protean careers emphasize the initiative and responsibility of employees for their careers (Hall, 1976, 2004). The vignettes offered by Sullivan and Arthur (2006) to illustrate boundary- 
less careers include a reduction of career aspirations in favor of family life, a career plateau of a highly qualified specialist with intended job change, and an increase in qualifications in order to quit employment for founding a home-based business. All these examples represent self-initiated and deliberate transitions. The protean career occurs mostly as a set of career-related attitudes (Baruch, 2014; Briscoe, Hall, \& Frautschy DeMuth, 2006). The concept behind it has idealistic and emancipative connotations: "The protean person's own personal career choices and search for self-fulfillment are the unifying or integrative elements in his or her life (Hall, 1976, p. 201)." In other words, protean career success takes into account personal development and the ability to follow one's dreams as the most important career success factor (Hall \& Chandler, 2005). In addition, it places the person's values above organizational goals (Hall, 2004). The respective measures of attitude usually come down to taking responsibility for one's career: "I am in charge of my own career," "I take responsibility for my own development," "I navigate my own career, mostly according to my plans" (Baruch, 2014), "I am in charge of my own career," "Ultimately, I depend upon myself to move my career forward" (Briscoe et al., 2006). For their validation, instruments were mainly applied to business students, managers, executives, and even former US Navy admirals. Unexpectedly, protean career orientations did not contrast with traditional work attitudes among ordinary employees in Vietnam and bus drivers in New Zealand (Baruch, 2014). High protean scores were negatively related to the intention to quit the job in the Vietnam sample and positively related to traditional career attitudes and affective organizational commitment among New Zealand bus drivers. Against this backdrop, one may question the validity of protean attitude measures across the whole 
range of qualification levels, jobs, and cultures. Furthermore, there is only scarce evidence about the relation between these attitudes and real career pathways (Briscoe et al., 2006). And finally, the direction of causality is unclear.

Extending the scope to a broader spectrum of ordinary working people, the euphonic labels of "boundaryless careers" and "protean careers" can be easily misused to justify the leveling of workers' rights by disguising them as acts of liberation and means for achieving self-direction and self-actualization (cf. Ehrenreich, 2006). With regard to the emergence and popularity of these constructs over the recent decades, one may ask 'cui bono'? Was there a mass movement of workers and employees pressing employers to grant them the right to quit their jobs whenever they wanted, to work for lower wages with temp agencies, to work as contractors instead of regular employees with pension and health plans, or to hop from internship to internship instead of being regularly hired? Or do these postmodern work arrangements serve primarily employers' flexibility to adjust personnel costs to fluctuations in trade cycles and sales markets in a globalized economy? Usually, macro-economic demands precede the change in institutions, legislation, the value climate and ultimately individuals' values and attitudes (Schmidtchen, 1997). This is completely in line with the fundamental ideas of DST, embodiment, and finally Vygotsky's process of internalization (see Shotter, 1993; van Geert, 1999): Humans create mental concepts out of what they do (upward causality), and with these concepts they justify and consolidate what they do (downward causality). Axinn and Barber (1997) demonstrated impressively the precedence of doing before appraising in a longitudinal study: The longer unmarried couples cohabitated, the more critical their attitudes towards family formation became, and not vice 
versa. Consequently, the widely used prefix "self" in the recent career literature may often turn out to be an ex post facto self-adjustment to constraints and self-justification rather than self-initiation and self-direction. In the recent German ShellStudy (Shell Deutschland Holding, 2015) on more than 2,500 adolescents and young adults, "a secure job" was ranked (71 percent) highest among youngsters' job-related aspirations. Despite critical viewpoints (e.g., Wahba \& Bridwell, 1976) on Maslow's need hierarchy (Maslow, 1970), there can be no doubt that material and physical security needs are more basic than occupational self-actualization. For this reason, Waters, Briscoe, Hall and Wang (2014) included only persons without material hardship in their study on positive effects of protean attitudes among unemployed people because hardship would introduce "noise" into job search activities. They referred to Leana and Feldman (1995) who indeed found that "Workers who had greater responsibilities (e.g., having more children to support) seemed to feel greater pressure to get reemployed no matter the quality of the job (p. 1397)."

Although genuinely related to career development and a host of psychological variables, the concepts of protean and boundaryless careers originated from management and HRM research. In this arena, they experienced a boom parallel to the changing world of business and work in the last two decades of the $20^{\text {th }}$ century and thereafter. It is also in this arena that these concepts are heavily debated and critized (e.g., Ehrenreich, 2006; Inkson, Gunz, Ganesh, \& Roper, 2012; Tams \& Arthur, 2010; Mayrhofer, Meyer, \& Steyrer, 2007). Developmental psychology with its presumed value-free interest in the description, explanation, and optimization of human development (Baltes, Reese \& Nesselroade, 1988) usually treats macro-context as a neutral backdrop that can be described, e.g. in terms of 
collectivism vs. individualism, as a cultural property, but has neither political nor ideological valence. Context factors such as economic interests, economic power and legislation, political restrictions, structural constraints and social inequality, power inequality, ethnic discrimination etc. are usually delegated to sociology, political sciences, and allied disciplines. In contrast, the debate among business scholars on novel career concepts is exhilarantly frank and close to reality. Particularly the boundaryless career is critized for being a blurry albeit fashionable concept: "the term 'boundaryless' was not developed by scholars seeking an appropriate term to describe particular career phenomena, but diffused uncritically into the literature because of its currence as a conference banner and its attractiveness to organizational studies (Inkson et al., 2012, p. 326)." Further, the authors question the overemphasis on personal agency, the normalization of boundaryless careers by implicitely devaluing tradtional career pathways as stultifying, and the claimed predominance of boundaryless careers without supporting data. For the fil rouge of the present chapter, the arguments in the agency-structure debate illuminate the difference of viewpoints between vocational psychology and (some) management scholars: "In the vocational perspective the individual is the agent of his or her own career, but the organizational perspective assumes that organizations can control members' careers. A still wider perspective asserts that institutional forces, such as social class, gender, ethnicity, education and government regulation, also constrain even the most agentic career actors (Mayrhofer et al., 2007). In considering institutional influences on career, we find it impossible to ignore ideology. (Inkson et al., 2012, p. 327)." In an earlier writing Roper, Ganesh, and Inkson (2010) concluded that "boundaryless career discourse ... is a manifestation of wider neoliberal discourse that emphasizes 
individual rather than societal or organizational responsibility for economic and career outcomes (p. 673)." Such a framing of a scholarly debate in a wider political context is hard to find in psychology, e.g., in the voluminous research on entrepreneurship. Undeniably, boundaryless careers ("boundary crossing careers" in Inkson et al.'s terms) exist, but are restricted and mostly studied among professional, technical, and managerial groups who are able to exercise agency due to their excellent qualifications. For unskilled workers, women and minorities, boundaryless may simply mean unemployment, insecurity and anxiety (Inkson et al., 2012). In a similar vein, Tams and Arthur (2010) point to contextual constraints and boundaries for boundaryless careers and career-related agency in general such as employment settings, labor market intermediaries, industry fields, institutional resources conveyed through social networks and occupational groups, cultural expectations and ethnicity, popular sentiments, and global socio-economic trends (p. 633). Interestingly, these autors also conceptualize context as "interdependent" which moves closer to the DST ideas and contrasts with the traditional person-context split as outlined above: "An independent approach conceives contexts as an objective reality, external to the individual. Another approach is to see contexts and individual agency as mutually enacted through collaborative practices ... This framing of context is particularly relevant at the micro-level, in looking at interactions among career actors ... An interdependent framing of agency also acknowledges the multilayered nature of contexts spanning from the immediate context of interpersonal interactions and organizations to macroforces at the level of industries, the economy, national cultures, and society (p. 638f.)."

In sum, the person vs. context or agency vs. structure debate has a long tradition in vocational psychology and shines 
through even in the early debate between Neff and Super when the field was clearly dominated by personal factors such as interests, aptitudes, and self-concept. Theory and research on vocational and career development have become increasingly interdisciplinary, now spanning departments of psychology, sociology, economics, management, and human resources. Although career development has considered context for a while, the nature of the person-context transaction is often ill-defined. Do autonomous agents cope with contextual givens or are individuals embodiments of interactions with contexts or both? The widely-used term "contextual givens" for the animate part of context is misleading. With regard to psychology the term reveals a certain naiveté. Even the macro-context is not a stage design but consists of other human actors, either in individual or organized form with diverse interests and different power. Human beings do not enter the stage like Martians and simply look how they can get along with the "givens". From their very first cry, humans are embedded and raised in a highly complex context structure of interests, power, and culture represented by other individuals and man-made organizations. These contexts with their boundaries and opportunities are not simply external forces that individuals must struggle with or adapt to. From a DST perspective, contexts find their way into individuals' personalities via accumulated day-to-day interactions and resulting experience. Although not rooted in DST, the concept of bounded agency (Shanahan \& Hood, 2000) accounts for context-induced constraints on person's choices and developmental pathways. However, it was again not psychologists who questioned an exaggerated emphasis on agency. Besides structural constraints, chance (Hirschi, 2010) and unconscious decisions (Krieshok, Black, \& McKay, 2009) also represent delimiters of agency as prime factors in career development. 


\section{Personal epilogue - sociohistorical context and biography shaped our reasoning}

Coming back to my impression of minor differences between Fred and myself with regard to agency and structure, DST can provide a straightforward explanation as can Vygotsky's concept of internalization. Psychological researchers underlie the same processes as their subjects. Their mental concepts including their theoretical reasoning are inherent parts of their personalities which are to a high degree internalizations (embodiments) of accumulated action and interaction experiences. Hall, the inventor of the protean career, offers a felicitous example: "As I think about my ideas on the protean career (that is, a career that is self-determined, driven by personal values rather than organizational rewards, and serving the whole person, family, and "life purpose"), I realize just how much of that thinking came from what I observed and learned from my parents (Hall, 2004, p. 2)." Then he described his father's career pathway perfectly matching his concept and confessed that these internalized experiences had led him to his career choice of becoming an academic, i.e., being self-employed yet still getting a regular pay check (p. 3).

Fred's work life is a superb example of a boundary crossing and self-directed career trajectory. From his father's tiler shop in the Rhineland near Bonn to a full professor's and associate dean's position at Penn state, he crossed geographical as well as occupational borders more than once. Although his sister's previous emigration to the US may have served as a contextual facilitator, it was his own completely autonomous plan to navigate his life towards an academic career abroad from scratch, i.e., without speaking English, without having studied before, without any prior formal arrangements with regard 
to work. When the self-made man Fred became a researcher (after having graduated and worked as a clinical psychologist, another boundary crossing), the theoretical arena in vocational psychology was dominated by approaches like Super's emphasising self-concept, match between self-concept, aptitude and occupation, and planning. Insofar, prevailing theories and Fred's biography were an almost perfect match, with the only exception that he may be regarded as a positive outlier on all career-related constructs starting with the prefix "self". Consequently, he was selected to the Outstanding Young Men of America in 1972.

My story differs. I graduated from high school in 1974 in the aftermath of the 1968 student rebellion, held sceptical attitudes towards state institutions, was opposed to the political viewpoints of my family, and did not really know what to study. As a half-orphan and refugee kid from the GDR, I was raised with a blend of unlimited maternal love and very limited material resources. A secure career choice seemed to be secondary school teacher. However, decreasing birth rates and ensuing spending cuts in the educational sector presented a bleak outlook. I became a psychologist, an enthusiastic clinician burning for the brand-new ideas of social psychiatry. My numerous job applications, albeit with a straight $\mathrm{A}$ university degree, never suceeded. When I ran out of money, a friend gave me a job ad for the "Berlin Youth Longitudinal study", I became a researcher, one-year contract first, then twelve contracts in six years, became a $\mathrm{PhD}$, wanted to cross the boundary to business. The same friend gave me a job ad for a commercial opinion research institute, I was hired as senior researcher, turned down a top level offer from a competitor for family reasons, went back to the academic sphere with the mediation of my former PhD advisor Rainer Silbereisen etc. 
... In essence, my career trajectory was much more coined by context and chance, regardless of unconscious decisions and heuristics I don't have access to. However, despite my more critical view of agency, I have always profited from Fred's planfulness, rigor, and perseverance as expressed in his smooth admonition: "You may want to get this done by tomorrow!"

\section{References}

Alwin, D. F. (1994). The stability of individual differences over the adult life span. In D. L. Featherman, R. M. Lerner \& M. Perlmutter (Eds.), Life-span development and behavior (Vol. 12, pp. 135-185). Hillsdale, NJ: Erlbaum.

Anbuhl, M. (2012). „Generation abgehängt“ - Was verbirgt sich binter den mehr als 2,2 Millionen jungen Menschen ohne Berufsabschluss? [What is behind the more than 2.2 million young people without vocational training?]. Berlin: DGB Bundesvorstand, Abteilung Bildungspolitik und Bildungsarbeit.

Arnett, J. J. (2000). Emerging adulthood: A theory of development from late teens through the twenties. American Psychologist, 55, 469-480.

Arnett, J. J. (2004). Emerging adulthood: The winding road from the late teens through the twenties. New York, NY: Oxford University Press.

Arthur, M. B. (1994). The boundaryless career: A new perspective for organizational inquiry. Journal of Organizational Behavior, 15, 295-306.

Axinn, W. G., \& Barber, J. S. (1997). Living arrangements and family formation attitudes in early adulthood. Journal of Marriage and the Family, 59, 595-611.

Baltes, P. B., Reese, H. W., \& Nesselroade, J. R. (1988). Life-span developmental psychology: Introduction to research methods. Hillsdale, NJ: Erlbaum.

Baruch, Y. (2014). The development and validation of a measure for protean career orientation. The International Journal of Human Resource Management, 25, 2702-2723.

Beck, U. (1992). Risk Society: Towards a new modernity. London: Sage.

Blossfeld, H.-P. (1989). Kohortendifferenzierung und Karriereprozess [Cohort differentiation and career process]. Frankfurt/Main: Campus.

Bourdieu, P. (1982). Die feinen Unterschiede. Kritik der gesellschaftlichen Urteilskraft [The subtle differences. Critique of societal judgment]. Frankfurt/ Main: Suhrkamp.

Briscoe, J. P., Hall, D. T., \& Frautschy DeMuth, R. L. (2006). Protean and boundaryless careers: An empirical exploration. Journal of Vocational Behavior, 69(1), 30-47.

Bronfenbrenner, U. (1979). The ecology of human development. Experiments by nature and design. Cambridge, MA: Harvard University Press. 
Burns, J. M. (2010). Leadership (Harper Perennial political classics edition). New York: Harper Perennial.

Bynner, J. (2001). British youth transitions in comparative perspective. Journal of Youth Studies, 4, 5-23.

Bynner, J. (2005). Rethinking the youth phase of the life-course: The case for emerging adulthood? Journal of Youth Studies, 8(4), 367-384.

Bynner, J., \& Parsons, S. (2002). Social exclusion and the transition from school to work: The case of young people not in education, employment, or training (NEET). Journal of Vocational Behavior, 60, 289-309.

Bynner, J., Ferri, E., \& Shepherd, P. (1997). Changing lives in the 1990s. In J. Bynner, E. Ferri \& P. Shepherd (Eds.), Twenty-something in the 1990 s. Getting on, getting by, getting nowhere (pp. 1-10). Aldershot, UK: Ashgate.

Côté, J., \& Bynner, J. M. (2008). Changes in the transition to adulthood in the UK and Canada: The role of structure and agency in emerging adulthood. Journal of Youth Studies, 11(3), 251-268.

Ehrenreich, B. (2006). Bait and switch: The (futile) pursuit of the American dream. New York: Henry Holt.

Ford, D. H. (1994). Humans as self-constructing living-systems: A developmental perspective on behavior and personality ( $2^{\text {nd }}$ ed.). State College, PA: Ideals.

Ford, D. H., \& Lerner, R. M. (1992). Developmental systems theory: An integrative approach. Newbury Park, CA: Sage Publications.

Furlong, A., \& Cartmel, F. (1997). Young people and social change. Individualization and risk in late modernity. Buckingham, UK: Open University Press.

Gershuny, J., \& Pahl, R. (1996). Life-time employment in a new context. Paper presented at the conference on Challenges of Unemployment in a Regional Europe. Ljouwert, NL, Fryske Academy.

Ginzberg, E., Ginsburg, S., Axelrad, S., \& Herma, J. (1951). Occupational choice: An approach to a general theory. New York, NY: Columbia University Press.

Granic, I., \& Patterson, G. R. (2006). Toward a comprehensive model of antisocial development: A dynamic systems approach. Psychological Review, 113(1), 101-131.

Hall, D. T. (1976). Careers in organizations. Glenview, IL: Scott, Foresman.

Hall, D. T. (2004). The protean career: A quarter-century journey. Journal of Vocational Behavior, 65, 1-13.

Hall, D. T., \& Chandler, D. E. (2005). Psychological success: When the career is a calling. Journal of Organizational Behavior, 26, 155-176.

Hirschi, A. (2010). The role of chance events in the school-to-work transition: The influence of demographic, personality and career development variables. Journal of Vocational Behavior, 77, 39-49.

Inkson, K., Gunz, H., Ganesh, S., \& Roper, J. (2012). Boundaryless careers: Bringing back boundaries. Organization Studies, 33, 323-340.

Joshi, H., \& Paci, P. (1997). Life in the labor market. In J. Bynner, E. Ferri \& P. Shepherd (Eds.), Twenty-something in the 1990s. Getting on, getting by, getting nowhere (pp. 31-52). Aldershot, UK: Ashgate. 
Krieshok, T. S., Black, M. D., \& McKay, R. A. (2009). Career decision making: The limits of rationality and the abundance of non-conscious processes. Journal of Vocational Behavior, 75, 275-290.

Leana, C. R., \& Feldman, D. C. (1995). Finding new jobs after a plant closing: Antecedents and outcomes of the occurrence and quality of reemployment. Human Relations, 48, 1381-1401.

Lewis, M. D. (2000). Emotional self-organization in three time scales. In M. D. Lewis \& I. Granic (Eds.), Emotion, development, and self-organization: Dynamic systems approaches to emotional development (pp. 37-69). Cambridge, MA: Cambridge University Press.

Lewis, T., Stone, J., III, Shipley, W., \& Madzar, S. (1998). The transition from school to work. An examination of the literature. Youth \& Society, 29, 259-292.

Maslow, A. H. (1970). Motivation and personality (2nd ed.). New York: Harper and Row.

Mayrhofer, W., Meyer, M., \& Steyrer, J. (2007). Contextual issues in the study of careers. In H. Gunz \& M. Peiperl (Eds.), Handbook of career studies (pp. 215-240). Thousand Oaks, CA: Sage.

Neff, W. S. (1941). Foreign policy and peace. New York: American Peace Mobilization.

Neff, W. S. (1968). Work and human behavior. New York: Atherton Press.

Neff, W. S. (1970). Walter Neff responds to Donald Super. American Journal of Orthopsychiatry, 40, 549-550.

Noam, G. G. (1999). The psychology of belonging: Reformulating adolescent development. In A. H. Esman, L. T. Flaherty \& H. A. Horowitz (Eds.), Adolescent psychiatry: Development and clinical studies, (Vol. 24, pp. 49-68). Mahwah, NJ: Analytic Press.

Nowak, A., Vallacher, R. R., \& Zochowski, M. (2005). The emergence of personality: Dynamic foundations of individual variation. Developmental Review, 25, 351-385.

OECD (1998). Getting started, settling in. OECD employment outlook. Paris: OECD.

Overton, W. F. (1998). Developmental psychology: Philosophy, concepts, and methodology. In W. Damon \& R. M. Lerner (Eds.), Handbook of child psychology (Vol. 1, pp. 107-188). New York: Wiley.

Overton, W. F. (2007). A coherent metatheory for dynamic systems: Relational organicism-contextualism. Human Development, 50, 154-159.

Perrone, P. A. (1970). Review of "Work and Human Behavior" (Neff, 1968). The Journal of Human Resources, 5, 259-260.

Putnam, R. D. (1999). Bowling alone: The collapse and revival of American community. New York, NY: Simon \& Schuster.

Reitzle, M. \& Silbereisen, R. K. (1999). Der Zeitpunkt materieller Unabhängigkeit und seine Folgen für das Erwachsenwerden [Timing of financial independence and its consequences for becoming adult]. In R. K. Silbereisen \& J. Zinnecker (Hrsg.), Entwicklung im sozialen Wandel (pp. 131-152). Weinheim: Psychologie Verlags Union. 
Reitzle, M. \& Vondracek, F. W. (2000). Methodological Avenues for the study of career pathways. Journal of Vocational Behavior, 57, 445-467.

Reitzle, M., Vondracek, F. W., \& Silbereisen, R. K. (1998). Timing of school-towork transitions: A developmental-contextual perspective. International Journal of Behavioral Development, 22, 7-28.

Roper, J., Ganesh, S., \& Inkson, K. (2010). Neoliberalism and knowledge interests in boundaryless careers discourse. Work, Employment and Society, 24, 661-679.

Savickas, M. L. (1995). Donald E. Super (1910-1994). American Psychologist, $50,794-795$.

Schmidtchen, G. (1997). Wie weit ist der Weg nach Deutschland? Sozialpsychologie der Jugend in der postsozialistischen Welt [How far is the route to Germany? Social psychology of youth in the post-socialist world]. Opladen: Leske + Budrich.

Shanahan, M. J., \& Hood, K. E. (2000). Adolescents in changing social structures: Bounded agency in life course perspective. In L. J. Crockett \& R. K. Silbereisen (Eds.), Negotiating adolescence in times of social change (pp. 123-134). New York: Cambridge University Press.

Shell Deutschland Holding (Ed.). (2015). Jugend 2015: Eine pragmatische Generation im Aufbruch [Youth 2015: A pragmatic generation on departure]. Frankfurt/Main: Fischer Taschenbuch.

Shotter, J. (1993). Bakhtin and Vygotsky: Internalization as a boundary phenomenon. New Ideas in Psychology, 11, 379-390.

Silbereisen, R. K., \& Eyferth, K. (1986). Development as action in context. In R. K. Silbereisen, K. Eyferth \& G. Rudinger (Eds.), Development as action in context. Problem behavior and normal youth development (pp. 3-16). Berlin: Springer.

Sullivan, S. E., \& Arthur, M. B. (2006). The evolution of the boundaryless career concept: Examining physical and psychological mobility. Journal of Vocational Behavior, 69, 19-29.

Super, D. E. (1953). A theory of vocational development. American Psychologist, $8,185-190$.

Super, D. E. (1956). Vocational development: The process of compromise or synthesis. Journal of Counseling Psychology, 3, 249-253.

Super, D. E. (1969a). Vocational developmental psychology: Persons, positions and processes. Counseling Psychologist, 1, 2-8.

Super, D. E. (1969b). Vocational development theory in 1988: How will it come about? Counseling Psychologist, 1, 9-14.

Super, D. E. (1970). Review of "Work and Human Behavior" (Neff, 1968). American Journal of Orthopsychiatry, 40, 163-167.

Super, D. E. (1980). A life-span, life-space, approach to career development. Journal of Vocational Behavior, 16, 282-298.

Tams, S., \& Arthur, M. B. (2010). New directions for boundaryless careers: Agency and interdependence in a changing world. Journal of Organizational Behavior, 31, 629-646. 
Thelen, E., \& Smith, L. B. (1994). A dynamic systems approach to the development of cognition and action. Cambridge, MA: The MIT Press.

van Geert, P. (1999). Vygotsky's dynamic systems. In P. Lloyd \& C. Fernyhough (Eds.), Lev Vygotsky: Critical assessments: Future directions (Vol. IV, pp. 3-21). Florence, KY: Routledge.

van Geert, P., \& Steenbeek, H. (2005). Explaining after by before: Basic aspects of a dynamic systems approach to the study of development. Developmental Review, 25, 408442.

Vondracek, F. W., Ford, D. H., \& Porfeli, E. J. (2014). A living systems theory of vocational behavior and development. Rotterdam: SensePublishers.

Vondracek, F. W., Lerner, R. M., \& Schulenberg, J. E. (1986). Career development: A life-span developmental approach. Hillsdale, NJ: Erlbaum.

Wahba, M. A., \& Bridwell, L. G. (1976). Maslow reconsidered: A review of research on the need hierarchy theory. Organizational Behavior \& Human Performance, 15, 212-240.

Waters, L., Briscoe, J. P., Hall, D. T., \& Wang, L. (2014). Protean career attitudes during unemployment and reemployment: A longitudinal perspective. Journal of Vocational Behavior, 84, 405-419.

Williamson, H. (1997). Status Zer0 youth and the 'underclass'. In R. MacDonald (Ed.), Youth, the 'underclass' and social exclusion (pp. 70-82). London: Routledge.

Witherington, D. C. (2007). The dynamic systems approach as metatheory for developmental psychology. Human Development, 50, 127-153.

Witherington, D. C. (2011). Taking emergence seriously: The centrality of circular causality for dynamic systems approaches to development. Human Development, 54, 66-92.

Wyn, J., \& White, R. (2000). Negotiating social change. The paradox of youth. Youth \& Society, 32, 165-183. 